\title{
Integrated Effect of Nutrient and Pesticide Management on Production and Productivity of Rice Variety Pusa Basmati-1509
}

\author{
Anurag Dhankar ${ }^{1}$, B.N. Tripathi ${ }^{1}$, Ravi Dhanker ${ }^{1}$, R.K. Pathak ${ }^{1}$, Anil Kumar ${ }^{1}$, \\ Puspendra Kumar ${ }^{2}$ and Vivek Kumar ${ }^{1}$
}

\author{
${ }^{1}$ Department of Soil Science \& Agricultural Chemistry, ${ }^{2}$ Department of Agronomy, C.S. Azad
} University of Agriculture and Technology, Kanpur-208 002 (Uttar Pradesh), India

*Corresponding author

\section{A B S T R A C T}

\begin{tabular}{l} 
K e y w o r d s \\
$\begin{array}{l}\text { Pesticide, Nutrient, } \\
\text { Biological yield, } \\
\text { Hulling, Milling, } \\
\text { Grain yield, Straw } \\
\text { yield }\end{array}$ \\
\hline Article Info \\
$\begin{array}{l}\text { Accepted: } \\
18 \text { July } 2020 \\
\text { Available Online: } \\
10 \text { August } 2020\end{array}$ \\
\hline
\end{tabular}

A field experiment was conducted during two consecutive years of Kharif2016 and 2017at Fertilizer Research Farm Uttari Pura, Chandra Shekhar Azad University of Agriculture and Technology, Kanpur (Uttar Pradesh). The field experiment was imposed to find out the influence of fertilizer nutrients and pesticides on the yield attributes and quality, nutrients uptake, soil health and various quality parameters of basmati rice PB-1509. The experiment was laid out in a split-plot design comprise of four main plot and ten sub-plot, in which main plots are: Control, Weedicide : Bispyribac Sodium (Nomnigold) $10 \% \mathrm{SC}$ @ 35 a.i. ha $^{-1}$, Fungicides : IFC- 110 (Tricyclazole $45 \%+$ Hexaconazole $10 \%$ WG ) 1.0 $\mathrm{g} /$ lit., Insecticides : Malathion $25 \%$ @ $25 \mathrm{~kg} \mathrm{ha}^{-1}$. The treatment combinations in sub-plots are viz., $\mathrm{N}\left(\mathrm{T}_{1}\right), \mathrm{NP}\left(\mathrm{T}_{2}\right), \mathrm{NPK}\left(\mathrm{T}_{3}\right), \mathrm{NPK}+\mathrm{Zn}\left(\mathrm{T}_{4}\right), \mathrm{NPK}+\mathrm{Fe}\left(\mathrm{T}_{5}\right), \mathrm{NPK}+\mathrm{Mn}\left(\mathrm{T}_{6}\right)$, $\mathrm{NPK}+\mathrm{Zn}+\mathrm{Fe}+\mathrm{Mn}\left(\mathrm{T}_{7}\right), \mathrm{NPK}+10 \mathrm{t} \mathrm{FYM} \mathrm{ha}^{-1}\left(\mathrm{~T}_{8}\right), \mathrm{NPK}+\mathrm{Zn}+\mathrm{Fe}+\mathrm{Mn}+$ Vermicompost @ 3 ton $\mathrm{ha}^{-1}\left(\mathrm{~T}_{9}\right)$, Control $\left(\mathrm{T}_{10}\right)$.The application of Weedicide : Bispyribac Sodium (Nomnigold)10\% SC @ 35 a.i. ha ${ }^{-1}$ at 4-6 leaves in treatment $\left(\mathrm{T}_{8}\right)$ stage was recorded highest biological yield, hulling and milling percentage along with grain and straw yield as compared to control treatment during both of the year observation. The application of Insecticides: Malathion 25\% @ $25 \mathrm{~kg} \mathrm{ha}^{-1}$ were also noticed higher production and productivity of basmati rice in comparison to insecticide application during both of the years.

\section{Introduction}

Rice is one of the most important field crops of the world providing staple food to millions. It is grown in 114countries across the world and the population of 150 million has continuing cultivation in near $11 \%$ of the world's cultivated land about 148 million hectares with a production of 710 million tons (FAO, 2011). Out of this almost $90 \%$ of rice production and consumption take place in Asian countries (Islam et al., 2010). In Asia, the largest rice-producing countries include China, India, Indonesia, Bangladesh, and Pakistan (FAO, 2011). 
Basmati rice is traditionally grown in the Himalayan foothill regions of India and Pakistan and the name is traditionally associated with this geographical origin (Bligh, 2000). In general, although the production of basmati rice varieties in all over coastal and foothill areas of our country is concentrated in north-west Indian statesHaryana, Punjab, Western Uttar Pradesh, and to a limited extent in Uttrakhand, Himachal Pradesh, and Jammu \& Kashmir.

The Green Revolution technologies led to the emergence of Rice-Wheat as the major cropping system in the IGP, which now ranks first among the 30 major cropping systems identified in India (Das, 2006). The share of Haryana in total basmati production generally marks at 43.8 percent followed by Punjab with 34.7 percent and Uttar Pradesh with 19.2 percent. Haryana and Punjab together constituted more than 75 percent of basmati rice produced in India. Total paddy acreages in Uttar Pradesh are estimated at 1614.1 thousand hectares in 2019 which is $21 \%$ higher than the last year acreage of 1336.1 thousand hectares. Basmati acreages in 2019 are estimated at 463.6 thousand hectares which are $84 \%$ higher than the last year acreage of 252.1 thousand hectares (APEDA 2019).

Rice production is needed to meet the food demands of the rapidly expanding population (Liu et al., 2016). Declining soil fertility may be one of the most important reasons for this yield stagnation. To improve soil fertility, especially soil organic carbon (SOC) content, has an important role in maintaining a sustainable increase in rice yield (Zhao et al., 2016).

\section{Materials and Methods}

At field experiment will be conducted at Fertilizer research Farm Uttari Pura, of Chandra Shekhar Azad University of
Agriculture \& Technology, Kanpur for two the consecutive year of 2015-16 and 201617in Kharif season. The initial Physicochemical and mechanical characteristics of the experimental soil were: sand $57.66 \%$, silt $22.30 \%$ and clay $20.14 \%$, mild high in reaction ( $\mathrm{pH} 8.32)$, and low EC 0.46 medium in organic carbon $(0.41 \%)$ with $182,11.70$ and $171.0 \mathrm{~kg} \mathrm{ha}^{-1}$ of available $\mathrm{N}, \mathrm{P}$, and $\mathrm{K}$, respectively. DTPA extractable $\mathrm{Zn}$, was 1.83 $\mathrm{mg} \mathrm{Kg}{ }^{-1}, \mathrm{Fe} \mathrm{12.7}$, and $\mathrm{Mn} 7.26 \mathrm{mg} \mathrm{Kg}^{-1}$, respectively. Forty treatment combinations were replicated three times in split-plot design.

Surface $(0-0.15 \mathrm{~cm})$ soil samples taken after the harvest of Rice were analyzed for $\mathrm{pH}$, organic carbon, cation exchange capacity, available $\mathrm{N}, \mathrm{P}$, and $\mathrm{K}$ using standard analytical methods. Besides, different fractions of $\mathrm{N}, \mathrm{P}, \mathrm{K}$, and $\mathrm{Zn}$ were also determined in the soil samples taken after the rice harvest and the composite soil samples drawn from adjacent fallow plots. The productivity of rice (2015-16 and 2016-17) was also recorded.

All the treatments were evaluated in a splitplot design with three replication. Twenty-one days old seedlings of 'Pusa Basmati-1509' rice were transplanted in the third week of July in each year with $20 \times 10 \mathrm{~cm}$ row to row and plant to plant spacing. The half dose on nitrogen and full doses of $\mathrm{P}, \mathrm{K}, \mathrm{Zn}, \mathrm{Mn}$, and Fe were applied as basal at the time of transplanting through ammonium sulfate, single super phosphate, Muriate of Potash (MOP), $\mathrm{MnSO}_{4}$ and $\mathrm{FeSO}_{4}$, respectively and remaining nitrogen was applied in two equal splits at maximum tillering and panicle initiation stage.

After taking the weight of total biomass, the produce of each net plot was threshed separated manually. The grains of each plot were cleaned and air dried to maintain the moisture content at a standard level of 14 
percent and recorded the weight in $\mathrm{kg}$ per net plot by balance. Finally, grain yield per plot was converted into $\mathrm{q} / \mathrm{ha}$ by the conversion factor. The straw yield was recorded by subtracting the weight of grains from the weight of the total harvested produced of each net plot. Thus the straw yield obtained in $\mathrm{kg} / \mathrm{plot}$ was multiplied with the conversion factor to get the straw yield in $q / h a$. The biological yield was calculated by using the formula based on grain and straw yield per q/ha.

Samples were analysed for their nitrogen content by the modified Kjddahl method (Jackson, 1973), phosphorus was determined by vanadomolybdate, yellow color method, and potassium by flame photometer in the diacid digest. Zinc, iron, and manganese contents were determined on the atomic absorption spectrophotometer. Organic cation in post-harvest soil was determined by Walkley and Black method. Available nitrogen, phosphorus, and potassium in soil samples were determined by the methods described by Subbiah and Asija (1956), Olsen's, and flame photometer (Jackson, 1973), respectively.

\section{Hulling percentage}

Well dried rough rice sample from each plot weighing $100 \mathrm{~g}$ were hulled in a mini "Satake Rice Whitening and Caking Machine" and the weight of brown rice was recorded. Hulling percentage was worked out as:

Hulling percentage $(\%)=$ $\frac{\text { Weight of brown rice }(\mathrm{g})}{\text { Weight of rough rice }(\mathrm{g})} \times 100$

\section{Milling percentage}

The hulled brown rice sample were milled in a "Satake Rice Whitening and Caking
Machine" for 5 minute. The polished rice was weighted and milling percentage was calculated as:

Milling $(\%)=\frac{\text { Weight of milled rice }(\mathrm{g})}{\text { Weight of rough rice }(\mathrm{g})} \times 100$

Head rice obtained after milling was weighed and the head rice recovery was calculated by using the following formula (Bandyopadhyay and Roy, 1992).

Head rice recovery $(\%)=$

$\frac{\text { Weight of whole milled rice }(\mathrm{g})}{\text { Weight of rough rice }(\mathrm{g})} \times 100$

\section{Grain yield (q ha $\left.{ }^{-1}\right)$}

After taking the weight of total biomass, the produce of each net plot was threshed separated manually. The grains of each plot were cleaned and air dried to maintain the moisture content at standard level of 14 per cent and recorded the weight in $\mathrm{kg}$ per net plot by balance. Finally grain yield per plot was converted in to $\mathrm{q} / \mathrm{ha}$ by conversion factor.

\section{Straw yield (q ha $\left.{ }^{-1}\right)$}

Straw yield was recorded by subtracting the weight of grains from the weight of total harvested produced of each net plot. Thus the straw yield obtained in $\mathrm{kg} / \mathrm{plot}$ was multiplied with the conversion factor in order to get the straw yield in $\mathrm{q} / \mathrm{ha}$.

\section{Results and Discussion}

\section{Effect of pesticides application on biological yield}

A perusal of the data (Table 1) revealed that the biological yield $\left(\mathrm{q} \mathrm{ha}^{-1}\right)$ differed significantly under different treatments. In general, the biological yield $\left(\mathrm{q} \mathrm{ha}{ }^{-1}\right)$ was 
highest during first year as compared to second year. The biological yield ranged was between 57.37 and $71.65 \mathrm{q} \mathrm{ha}^{-1}$, respectively during first year of the experiment. The biological yield was observed highest with the application of Weedicide : Bispyribac Sodium (Nomnigold)10\% SC @ 35 a.i. ha ${ }^{-1}$ at 4-6 leaves stage which was significantly superior over all the treatments during first year. The least value of biological yield was analyzed under control treatment during 2015-16. All the treatments were achieved more biological yield in comparison to control treatment during first year. Similar finding was also reported by Esfahani et al., (2014).

Further examined the data the second year biological yield ranged varied from 58.71 to $72.99 \mathrm{q} \mathrm{ha}^{-1}$ under control to Weedicide : Bispyribac Sodium (Nomnigold)10\% SC @ 35 a.i. ha $^{-1}$ at 4-6 leaves stage, respectively. The biological yield increased with increasing the doses of pesticide during both the year. The control treatment was exhibited inferiority in comparison to all the treatments during the observations period (Table 1).

It is perusal the data given in Table 1, the biological yield was also noticed significantly higher with the application of Insecticides: Malathion 25\%@25 kg ha ${ }^{-1}$, which was significantly higher over rest of the pesticides treatments during both of the year.

\section{Effect of pesticides application on grain yield (q ha $\left.{ }^{-1}\right)$}

The data depicted in (Table 5) indicate that application of weedicide : Bispyribac Sodium (Nomnigold) $10 \%$ SC @ 35 a.i. ha ${ }^{-1}$ at 4-6 leaves stage was increased grain yield significantly over control treatment. In grain yield, it varied from 24.02 and $24.69 \mathrm{q} \mathrm{ha}^{-1}$ in control treatment to 30.75 and $31.42 \mathrm{q} \mathrm{ha}^{-1}$ in plot where Weedicide : Bispyribac Sodium (Nomnigold) $10 \%$ SC @ 35 a.i. ha ${ }^{-1}$ at 4-6 leaves stage was applied during both the year of study. The application of Weedicide : Bispyribac Sodium (Nomnigold) 10 \% SC @ 35 a.i. ha ${ }^{-1}$ at 4-6 leaves stage was significantly superior over all the treatments during both the year of investigation. The application of Weedicide : Bispyribac Sodium (Nomnigold) $10 \%$ SC @ 35 a.i. ha ${ }^{-1}$ at 4-6 leaves stage, Insecticides : Malathion 25\%@ $25 \mathrm{~kg} \mathrm{ha}{ }^{-1}$ and Fungicides : IFC- 110 (Tricyclazole $45 \%+$ Hexaconazole $10 \%$ WG) $1.0 \mathrm{~g} /$ lit were 21.88 and $21.42 \%, 15.92$ and $15.56 \%$ and 7.96 and $7.30 \%$ higher over control treatment, respectively during both the year of investigation. Similar finding was also reported by Singh and Chhokar (2009).

Further examined the data, The grain yield was found maximum with the application of Weedicide : Bispyribac Sodium (Nomnigold) $10 \%$ SC @ 35 a.i. ha ${ }^{-1}$ at 4-6 leaves stage (20.40 to $41.97 \mathrm{q} \mathrm{ha}^{-1}$ in first year and 21.07 and $42.63 \mathrm{q} \mathrm{ha}^{-1}$ in second year, respectively) and minimum grain yield was observed in control plot (16.20 to $33.0 \mathrm{q} \mathrm{ha}^{-1}$ in first year and 16.87 and $33.67 \mathrm{q} \mathrm{ha}^{-1}$ in second year, respectively). Amongst pesticides treatments Weedicide : Bispyribac Sodium (Nomnigold) $10 \%$ SC @ 35 a.i. ha ${ }^{-1}$ at 4-6 leaves stage proved to be better than other treatments and all the sources behaved alike at their respective levels. Similar finding was also reported by Srivastava and Singh (2009)

\section{Effect of pesticides application on straw yield}

A perusal the data (Table 6) revealed that the straw yield $\left(\mathrm{q} \mathrm{ha} \mathrm{ha}^{-1}\right)$ differed significantly under different treatments. In general, the straw yield $\left(\mathrm{q} \mathrm{ha}^{-1}\right)$ was highest during first year as compared to second year. The straw yield ranged was between 33.35 and $40.90 \mathrm{q}$ $\mathrm{ha}^{-1}$, respectively during first year of the experiment. The straw yield was observed highest with the application of Weedicide : 
Bispyribac Sodium (Nomnigold)10 \% SC @ 35 a.i. ha $^{-1}$ at 4-6 leaves stage which was significantly superior over all the treatments during first year. The least value of straw yield was analyzed under control treatment during 2015-16. All the treatments were achieved more straw yield in comparison to control treatment during first year. Similar results have been reported by Singh et al., (2004), Tripathi et al., (2015).

Further examined the data the second year straw yield ranged varied from 34.02 to 41.57 $\mathrm{q}$ ha ${ }^{-1}$ under control to Weedicide : Bispyribac Sodium (Nomnigold)10\% SC @ 35 a.i. ha ${ }^{-1}$ at 4-6 leaves stage, respectively. The straw yield increased with increasing the doses of pesticide during both the year. The control treatment was exhibited inferiority in comparison to all the treatments during the observations period (Table 6).

\section{Effect of pesticides application on hulling $(\%)$ in rice grain}

The hulling percent in grain presented in (Table 2) indicate that hulling percent in rice grain was marked non significantly due to pesticide and nutrient application during both of the year. The hulling percent in grain was varied from 74.49 and 79.08 and 75.15 and $79.75 \%$ under control and Weedicide : Bispyribac Sodium (Nomnigold)10\% SC @ 35 a.i. ha ${ }^{-1}$ at 4-6 leaves stage during both of the year. This treatment was also superior over all the pesticides treatments during 201516 and 2016-17.

The application of Weedicide : Bispyribac Sodium (Nomnigold)10\% SC @ 35 a.i. ha ${ }^{-1}$ at 4-6 leaves stage was recorded highest hulling percent as compared to control treatment during both of the year observation. The application of control and Insecticides: Malathion 25\% @ $25 \mathrm{~kg} \mathrm{ha}^{-1}$ were also noticed higher hulling percent in comparison to insecticide application during both of the years. Similar finding was also reported by Dixit and Gupta (2000), Tejada and Hernandez, (2009)

\section{Effect of pesticides application on milling $(\%)$ in rice grain}

The milling percentin grain presented in Table 3 indicate that milling percent in rice grain was marked non significantly due to pesticide and nutrient application during both of the year. The miling percent in grain was varied from 62.95 and 67.68 and 63.62 and $68.32 \%$ under control and Weedicide : Bispyribac Sodium (Nomnigold)10\% SC @ 35 a.i. ha ${ }^{-1}$ at 4-6 leaves stage during both of the year. This treatment was also superior over all the pesticides treatments during 201516 and 2016-17. The application of Weedicide : Bispyribac Sodium (Nomnigold) $10 \%$ SC @ 35 a.i. ha ${ }^{-1}$ at 4-6 leaves stage was recoded highest milling percent as compared to control treatment during both of the year observation. The application of control and Insecticides: Malathion 25\% @ $25 \mathrm{~kg} \mathrm{ha}^{-1}$ were also noticed higher milling percentin comparison to insecticide application during both of the years. Similar finding was also reported by Bhosale and Vijayalaxmi (2015).

\section{Effect of pesticides application on head recovery $(\%)$ in rice grain}

The head recovery percent in grain presented in (Table 4) indicate that head recovery percent in rice grain was marked non significantly due to pesticide and nutrient application during both of the year. The head recovery percent in grain was varied from 58.70 and 63.46 and 59.36 and $64.23 \%$ under control and Weedicide : Bispyribac Sodium (Nomnigold)10\% SC @ 35 a.i. ha ${ }^{-1}$ at 4-6 leaves stage during both of the year. This treatment was also superior over all the 
pesticides treatments during 2015-16 and 2016-17. The application of Weedicide : Bispyribac Sodium (Nomnigold)10\% SC @ 35 a.i. ha $^{-1}$ at 4-6 leaves stage was recorded highest head recovery percent as compared to control treatment during both of the year observation. The application of control and Insecticides: Malathion 25\% @ $25 \mathrm{~kg} \mathrm{ha}^{-1}$ were also noticed higher head recovery percent in comparison to insecticide application during both of the years. Similar finding was also reported by Srivastav et al., (2009) and Kumar et al., (2017).

\section{Effect of nutrients application on biological yield}

It is clear from the Table 1 showed that the biological yield $\left(\mathrm{qha}^{-1}\right)$ was influenced significantly due to different nutrient applications during both of the year.

The biological yield $\left(\mathrm{qha}^{-1}\right)$ ranged was varied from 43.22 to $85.45 \mathrm{q} \mathrm{ha}^{-1}$ during first year and 44.56 to $86.78 \mathrm{qha}^{-1}$ during second year, respectively. Among the nutrient application, $\mathrm{NPK}+\mathrm{Zn}+\mathrm{Fe}+\mathrm{Mn}+$ Vermicompost @ 3 ton $\mathrm{ha}^{-1}$ application was recorded significantly highest biological yield $\left(\mathrm{qha}^{-1}\right)$ with the ranged 77.94 to $97.07 \mathrm{ha}^{-1}$ and 79.28 to 98.40 qha $^{-1}$ as compared to control treatment during both of the year. The lowest biological yield $\left(\mathrm{qha}^{-1}\right.$ ) was noticed in control plot viz., 39.21 and $47.82 \mathrm{qha}^{-1}$ to 40.54 to $49.15 \mathrm{qha}^{-1}$ during 2015-16 and 2016-17, respectively.

Further perusal the data given in (Table 1) indicate that the application of $\mathrm{NPK}+\mathrm{Zn}+\mathrm{Fe}$ $+\mathrm{Mn}$ and NPK +10 t FYM ha ${ }^{-1}$ was produced significantly higher biological yield $\left(\mathrm{qha}^{-1}\right)$ in comparison to rest of the nutrient application. The alone application of nitrogen was also recorded lowest biological yield $\left(\mathrm{qha}^{-1}\right)$ after control treatments during both the year of study.

\section{Effect of nutrients applications on hulling} $(\%)$ in rice grain

The ranges of variation in hulling percent in grain were 77.47 to $75.91 \%$ and 76.78 to $78.14 \%$ in first and second years, respectively. All the treatments had statistically higher hulling percent values than control. All the treatments were statistically superior to control in respect of hulling percent. Among the nutrients application levels hulling percent increase statistically with $\mathrm{NPK}+\mathrm{Zn}+\mathrm{Fe}+\mathrm{Mn}+$ Vermicompost @ 3 ton $\mathrm{ha}^{-1}$ as compare to control during both the year.

Addition of $\mathrm{Zn} \mathrm{Fe}$, Mn with NPK increased hulling in grain as in comparison of all nutrient applications during both the year (Table 2).Similar finding was also reported by Mrudula (2004), Yadav and Christopher lourduraj (2006), Tejada and Hernandez, (2009) and Tripathi et al., (2018).

\section{Effect of nutrients applications on milling $(\%)$ in rice grain}

The ranges of variation in milling percent in grain were 66.49 to $66.14 \%$ and 65.16 to $66.80 \%$ in first and second years, respectively. All the treatments had statistically higher milling percent values than control. All the treatments were statistically superior to control in respect of milling percent. Among the nutrients application levels milling percent increase statistically with $\mathrm{NPK}+\mathrm{Zn}+\mathrm{Fe}+\mathrm{Mn}+$ Vermicompost @ 3 ton $\mathrm{ha}^{-1}$ as compare to control during both the year.

Addition of $\mathrm{Zn} \mathrm{Fe}$, Mn with NPK increased milling in grain as in comparison of all nutrient applications during both the year (Table 3). Similar finding was also reported by Srivastav et al., (2009) and Kumar et al., (2017). 
Table.1 Effect of pesticide and nutrient applications on biological yield (q ha ${ }^{-1}$ ) rice crop during 2015-16 and 2016-17

\begin{tabular}{|c|c|c|c|c|c|c|c|c|c|c|}
\hline \multirow[t]{3}{*}{ Treatments } & \multicolumn{10}{|c|}{ Biological yield (q ha $\left.\mathbf{h}^{-1}\right)$} \\
\hline & \multicolumn{5}{|c|}{ 2015-16 } & \multicolumn{5}{|c|}{ 2016-17 } \\
\hline & Control & Weedicide & Fungicides & Insecticides & Mean & Control & Weedicide & Fungicides & Insecticides & Mean \\
\hline $\mathbf{N}$ & 43.80 & 57.45 & 50.10 & 55.00 & 51.59 & 45.13 & 58.78 & 50.77 & 56.33 & 52.75 \\
\hline NP & 49.88 & 64.79 & 56.74 & 62.25 & 58.42 & 51.22 & 66.13 & 58.07 & 63.58 & 59.75 \\
\hline NPK & 54.07 & 69.90 & 61.29 & 67.49 & 63.19 & 55.40 & 71.23 & 62.62 & 68.82 & 64.52 \\
\hline NPK + Zn & 59.76 & 75.48 & 64.64 & 71.27 & 67.79 & 61.10 & 76.81 & 65.30 & 72.60 & 68.95 \\
\hline $\mathrm{NPK}+\mathrm{Fe}$ & 56.84 & 67.94 & 66.42 & 66.66 & 64.46 & 58.17 & 69.28 & 67.75 & 68.00 & 65.80 \\
\hline $\mathrm{NPK}+\mathrm{Mn}$ & 55.08 & 67.25 & 63.72 & 64.90 & 62.74 & 56.42 & 68.58 & 65.05 & 66.23 & 64.07 \\
\hline $\mathrm{NPK}+\mathrm{Zn}+\mathrm{Fe}+\mathrm{Mn}$ & 70.80 & 87.00 & 73.97 & 77.28 & 77.26 & 72.13 & 88.33 & 75.30 & 78.61 & 78.60 \\
\hline NPK +10 t FYM ha ${ }^{-1}$ & 66.34 & 81.82 & 69.00 & 74.31 & 72.87 & 67.67 & 83.16 & 70.33 & 75.65 & 74.20 \\
\hline $\begin{array}{l}\mathrm{NPK}+\mathrm{Zn}+\mathrm{Fe}+\mathrm{Mn}+ \\
\text { Vermicompost @ } 3 \text { t ha }{ }^{-1}\end{array}$ & 77.94 & 97.07 & 80.43 & 86.36 & 85.45 & 79.28 & 98.40 & 81.76 & 87.70 & 86.78 \\
\hline Control & 39.21 & 47.82 & 41.40 & 44.47 & 43.22 & 40.54 & 49.15 & 42.73 & 45.81 & 44.56 \\
\hline \multirow[t]{2}{*}{ Mean } & $\mathbf{5 7 . 3 7}$ & 71.65 & 62.77 & 67.00 & & 58.71 & 72.99 & 63.97 & 68.33 & \\
\hline & $\mathbf{W}$ & $\mathbf{N}$ & & & & $\mathbf{W}$ & $\mathbf{N}$ & & & \\
\hline SEm & 0.57 & 0.39 & & & & 0.42 & 0.45 & & & \\
\hline CD@ $9 \%$ & 1.97 & 1.09 & & & & 1.46 & 1.26 & & & \\
\hline $\mathbf{C V}$ & 5.82 & 5.15 & & & & 5.50 & 5.85 & & & \\
\hline
\end{tabular}


Table.2 Effect of pesticide and nutrient applications on hulling (\%) of rice crop during 2015-16 and 2016-17

\begin{tabular}{|c|c|c|c|c|c|c|c|c|c|c|}
\hline \multirow[t]{3}{*}{ Treatments } & \multicolumn{10}{|c|}{ Hulling (\%) } \\
\hline & \multicolumn{5}{|c|}{$2015-16$} & \multicolumn{5}{|c|}{ 2016-17 } \\
\hline & Control & Weedicide & Fungicides & Insecticides & Mean & Control & Weedicide & Fungicides & Insecticides & Mean \\
\hline $\mathbf{N}$ & 73.73 & 78.42 & 75.67 & 77.06 & 76.22 & 74.40 & 79.09 & 76.34 & 77.72 & 76.89 \\
\hline NP & 73.94 & 78.64 & 76.16 & 77.29 & 76.51 & 74.61 & 79.30 & 76.83 & 77.95 & 77.17 \\
\hline NPK & 74.31 & 78.95 & 76.07 & 77.51 & 76.71 & 74.98 & 79.62 & 76.74 & 78.18 & 77.38 \\
\hline NPK $+\mathrm{Zn}$ & 74.56 & 79.54 & 76.36 & 77.73 & 77.05 & 75.23 & 80.20 & 77.03 & 78.40 & 77.71 \\
\hline $\mathrm{NPK}+\mathrm{Fe}$ & 76.46 & 79.09 & 76.28 & 77.64 & 77.37 & 77.13 & 79.76 & 77.28 & 78.30 & 78.12 \\
\hline NPK + Mn & 74.35 & 79.09 & 75.50 & 77.59 & 76.63 & 75.02 & 79.75 & 77.17 & 78.26 & 77.55 \\
\hline $\mathrm{NPK}+\mathrm{Zn}+\mathrm{Fe}+\mathrm{Mn}$ & 74.69 & 79.52 & 77.54 & 77.91 & 77.42 & 75.36 & 80.19 & 77.20 & 78.58 & 77.83 \\
\hline NPK +10 t FYM ha ${ }^{-1}$ & 74.62 & 79.43 & 76.48 & 77.82 & 77.09 & 75.29 & 80.09 & 77.14 & 78.49 & 77.75 \\
\hline $\begin{array}{l}\mathrm{NPK}+\mathrm{Zn}+\mathrm{Fe}+\mathrm{Mn}+ \\
\text { Vermicompost @ } 3 \mathrm{t} \mathrm{ha}^{-1}\end{array}$ & 74.86 & 80.29 & 76.71 & 78.03 & 77.47 & 75.53 & 80.96 & 77.38 & 78.69 & 78.14 \\
\hline Control & 73.36 & 77.87 & 75.57 & 76.84 & 75.91 & 74.03 & 78.54 & 76.24 & 77.50 & 76.58 \\
\hline Mean & 74.49 & 79.08 & 76.23 & 77.54 & & 75.15 & 79.75 & 76.93 & 78.21 & \\
\hline & $\mathbf{W}$ & $\mathbf{N}$ & & & & W & $\mathbf{N}$ & & & \\
\hline SEm & 0.97 & 0.58 & & & & 0.90 & 0.64 & & & \\
\hline CD@ $9 \%$ & NS & NS & & & & NS & NS & & & \\
\hline $\mathbf{C V}$ & 6.90 & 6.69 & & & & 6.34 & 7.16 & & & \\
\hline
\end{tabular}


Table.3 Effect of pesticide and nutrient applications on milling (\%) in grain of rice crop during 2015-16 and 2016-17

\begin{tabular}{|c|c|c|c|c|c|c|c|c|c|c|}
\hline \multirow[t]{3}{*}{ Treatments } & \multicolumn{10}{|c|}{ Milling (\%) } \\
\hline & \multicolumn{5}{|c|}{ 2015-16 } & \multicolumn{5}{|c|}{ 2016-17 } \\
\hline & Control & Weedicide & Fungicides & Insecticides & Mean & Control & Weedicide & Fungicides & Insecticides & Mean \\
\hline $\mathbf{N}$ & 62.40 & 67.09 & 64.34 & 66.06 & 64.97 & 63.06 & 67.76 & 65.01 & 66.39 & 65.55 \\
\hline NP & 62.61 & 66.97 & 64.50 & 65.95 & 65.01 & 63.28 & 67.30 & 65.16 & 66.62 & 65.59 \\
\hline NPK & 62.98 & 67.62 & 64.74 & 66.52 & 65.46 & 63.64 & 68.28 & 65.41 & 67.18 & 66.13 \\
\hline $\mathbf{N P K}+\mathrm{Zn}$ & 63.23 & 67.87 & 65.03 & 66.40 & 65.63 & 63.89 & 68.54 & 66.03 & 67.07 & 66.38 \\
\hline $\mathrm{NPK}+\mathrm{Fe}$ & 63.13 & 67.76 & 64.94 & 65.97 & 65.45 & 63.79 & 68.43 & 65.61 & 66.97 & 66.20 \\
\hline NPK + Mn & 63.02 & 67.75 & 64.84 & 65.26 & 65.22 & 63.68 & 68.42 & 65.50 & 65.93 & 65.88 \\
\hline $\mathrm{NPK}+\mathrm{Zn}+\mathrm{Fe}+\mathrm{Mn}$ & 63.36 & 68.19 & 65.21 & 66.58 & 65.83 & 64.02 & 68.86 & 66.21 & 67.25 & 66.58 \\
\hline NPK +10 t FYM ha ${ }^{-1}$ & 63.29 & 68.09 & 65.15 & 66.49 & 65.75 & 63.96 & 68.76 & 65.81 & 67.15 & 66.42 \\
\hline $\begin{array}{l}\mathrm{NPK}+\mathrm{Zn}+\mathrm{Fe}+\mathrm{Mn}+ \\
\text { Vermicompost @ } 3 \mathrm{t} \\
\text { ha }^{-1}\end{array}$ & 63.53 & 68.96 & 65.38 & 66.69 & 66.14 & 64.19 & 69.62 & 66.04 & 67.36 & 66.80 \\
\hline Control & 62.03 & 66.54 & 64.24 & 65.17 & 64.49 & 62.69 & 67.21 & 64.91 & 65.84 & 65.16 \\
\hline \multirow[t]{2}{*}{ Mean } & 62.95 & 67.68 & 64.84 & 66.11 & & 63.62 & 68.32 & 65.57 & 66.77 & \\
\hline & W & $\mathbf{N}$ & & & & W & $\mathbf{N}$ & & & \\
\hline SEm & 0.94 & 0.95 & & & & 0.92 & 0.53 & & & \\
\hline CD@ $9 \%$ & NS & NS & & & & NS & NS & & & \\
\hline $\mathbf{C V}$ & 7.85 & 12.60 & & & & 7.67 & 6.93 & & & \\
\hline
\end{tabular}


Table.4 Effect of pesticide and nutrient applications on head recovery (\%) in grain of rice crop during 2015-16 and 2016-17

\begin{tabular}{|c|c|c|c|c|c|c|c|c|c|c|}
\hline \multirow[t]{3}{*}{ Treatments } & \multicolumn{10}{|c|}{ Head recovery (\%) } \\
\hline & \multicolumn{5}{|c|}{ 2015-16 } & \multicolumn{5}{|c|}{ 2016-17 } \\
\hline & Control & Weedicide & Fungicides & Insecticides & Mean & Control & Weedicide & Fungicides & Insecticides & Mean \\
\hline $\mathbf{N}$ & 58.14 & 62.83 & 60.08 & 61.47 & 60.63 & 58.80 & 63.50 & 60.75 & 62.13 & 61.30 \\
\hline NP & 58.35 & 63.05 & 60.24 & 61.69 & 60.83 & 59.02 & 64.38 & 60.90 & 62.36 & 61.67 \\
\hline NPK & 58.72 & 63.36 & 60.48 & 61.26 & 60.95 & 59.39 & 64.36 & 61.15 & 61.92 & 61.70 \\
\hline $\mathbf{N P K}+\mathbf{Z n}$ & 58.97 & 63.61 & 60.77 & 61.47 & 61.20 & 59.63 & 64.28 & 61.77 & 62.81 & 62.12 \\
\hline $\mathrm{NPK}+\mathrm{Fe}$ & 58.87 & 63.50 & 61.02 & 61.71 & 61.27 & 59.53 & 64.17 & 61.35 & 62.71 & 61.94 \\
\hline NPK + Mn & 58.76 & 63.49 & 60.58 & 62.00 & 61.21 & 59.42 & 64.16 & 61.25 & 62.67 & 61.87 \\
\hline $\mathrm{NPK}+\mathrm{Zn}+\mathrm{Fe}+\mathrm{Mn}$ & 59.10 & 63.93 & 60.95 & 62.32 & 61.57 & 59.76 & 64.60 & 61.61 & 62.99 & 62.24 \\
\hline NPK +10 t FYM ha-1 & 59.03 & 63.83 & 60.89 & 62.23 & 61.49 & 59.70 & 64.50 & 61.55 & 62.89 & 62.16 \\
\hline $\begin{array}{l}\mathrm{NPK}+\mathrm{Zn}+\mathrm{Fe}+\mathrm{Mn}+ \\
\text { Vermicompost @ } 3 \mathrm{t} \\
\mathrm{ha}^{-1}\end{array}$ & 59.27 & 64.70 & 61.12 & 62.43 & 61.88 & 59.93 & 65.36 & 61.79 & 63.10 & 62.55 \\
\hline Control & 57.77 & 62.28 & 59.98 & 61.24 & 60.32 & 58.43 & 62.95 & 60.65 & 61.91 & 60.99 \\
\hline Mean & 58.70 & 63.46 & 60.61 & 61.78 & & 59.36 & 64.23 & 61.28 & 62.55 & \\
\hline & $\mathbf{W}$ & $\mathbf{N}$ & & & & $\mathbf{W}$ & $\mathbf{N}$ & & & \\
\hline SEm & 1.15 & 0.71 & & & & 1.01 & 0.55 & & & \\
\hline CD@ 5\% & NS & NS & & & & NS & NS & & & \\
\hline $\mathbf{C V}$ & 10.26 & 10.10 & & & & 8.90 & 7.71 & & & \\
\hline
\end{tabular}


Table.5 Effect of pesticide and nutrients applications on grain yield ( $\mathrm{q} \mathrm{ha}^{-1}$ ) of rice crop during 2015-16 and 2016-17

\begin{tabular}{|c|c|c|c|c|c|c|c|c|c|c|}
\hline \multirow[t]{3}{*}{ Treatments } & \multicolumn{10}{|c|}{ Grain yield $\left(\mathrm{q} \mathrm{ha}^{-1}\right)$} \\
\hline & \multicolumn{5}{|c|}{ 2015-16 } & \multicolumn{5}{|c|}{ 2016-17 } \\
\hline & Control & Weedicide & Fungicides & Insecticides & Mean & Control & Weedicide & Fungicides & Insecticides & Mean \\
\hline $\mathbf{N}$ & 18.00 & 24.50 & 21.00 & 23.33 & 21.71 & 18.67 & 25.17 & 21.00 & 24.00 & 22.21 \\
\hline NP & 20.70 & 27.73 & 23.93 & 26.53 & 24.73 & 21.37 & 28.40 & 24.60 & 27.20 & 25.39 \\
\hline NPK & 22.57 & 30.00 & 26.13 & 28.87 & 26.89 & 23.23 & 30.67 & 26.80 & 29.53 & 27.56 \\
\hline $\mathbf{N P K}+\mathbf{Z n}$ & 24.97 & 32.47 & 27.40 & 30.50 & 28.83 & 25.63 & 33.13 & 27.40 & 31.17 & 29.33 \\
\hline $\mathrm{NPK}+\mathrm{Fe}$ & 23.80 & 29.00 & 25.60 & 28.40 & 26.70 & 24.47 & 29.67 & 26.27 & 29.07 & 27.37 \\
\hline NPK + Mn & 23.00 & 28.70 & 24.67 & 27.60 & 25.99 & 23.67 & 29.37 & 25.33 & 28.27 & 26.66 \\
\hline $\mathrm{NPK}+\mathrm{Zn}+\mathrm{Fe}+\mathrm{Mn}$ & 30.00 & 37.50 & 31.47 & 33.00 & 32.99 & 30.67 & 38.17 & 32.13 & 33.67 & 33.66 \\
\hline NPK +10 t FYM ha ${ }^{-1}$ & 28.00 & 35.27 & 29.23 & 31.70 & 31.05 & 28.67 & 35.93 & 29.90 & 32.37 & 31.72 \\
\hline $\begin{array}{l}\mathrm{NPK}+\mathrm{Zn}+\mathrm{Fe}+\mathrm{Mn}+ \\
\text { Vermicompost @ } 3 \text { ton } \\
\text { ha }^{-1}\end{array}$ & 33.00 & 41.97 & 34.30 & 37.03 & 36.58 & 33.67 & 42.63 & 34.97 & 37.70 & 37.24 \\
\hline Control & 16.20 & 20.40 & 17.27 & 18.77 & 18.16 & 16.87 & 21.07 & 17.93 & 19.43 & 18.83 \\
\hline \multirow[t]{2}{*}{ Mean } & 24.02 & 30.75 & 26.10 & 28.57 & & 24.69 & 31.42 & 26.63 & 29.24 & \\
\hline & W & $\mathbf{N}$ & & & & W & $\mathbf{N}$ & & & \\
\hline SEm & 0.40 & 0.20 & & & & 0.65 & 0.21 & & & \\
\hline CD@ 5\% & 1.39 & 0.56 & & & & 2.26 & 0.60 & & & \\
\hline $\mathbf{C V}$ & 8.02 & 6.24 & & & & 12.78 & 6.56 & & & \\
\hline
\end{tabular}


Table.6 Effect of pesticide and nutrients applications on straw yield (q ha ${ }^{-1}$ ) of rice crop during 2015-16 and 2016-17

\begin{tabular}{|c|c|c|c|c|c|c|c|c|c|c|}
\hline \multirow[t]{3}{*}{ Treatments } & \multicolumn{10}{|c|}{ Straw yield (q ha $\left.{ }^{-1}\right)$} \\
\hline & \multicolumn{5}{|c|}{ 2015-16 } & \multicolumn{5}{|c|}{ 2016-17 } \\
\hline & Control & Weedicide & Fungicides & Insecticides & Mean & Control & Weedicide & Fungicides & Insecticides & Mean \\
\hline $\mathbf{N}$ & 25.8 & 33.0 & 29.1 & 31.7 & 29.88 & 26.5 & 33.6 & 29.8 & 32.3 & 30.55 \\
\hline NP & 29.2 & 37.1 & 32.8 & 35.7 & 33.69 & 29.9 & 37.7 & 33.5 & 36.4 & 34.36 \\
\hline NPK & 31.5 & 39.9 & 35.2 & 38.6 & 36.29 & 32.2 & 40.6 & 35.8 & 39.3 & 36.96 \\
\hline $\mathbf{N P K}+\mathbf{Z n}$ & 34.8 & 43.0 & 37.2 & 40.8 & 38.95 & 35.5 & 43.7 & 37.9 & 41.4 & 39.62 \\
\hline NPK+ Fe & 33.0 & 38.9 & 40.8 & 38.3 & 37.76 & 33.7 & 39.6 & 41.5 & 38.9 & 38.43 \\
\hline NPK + Mn & 32.1 & 38.5 & 39.1 & 37.3 & 36.74 & 32.7 & 39.2 & 39.7 & 38.0 & 37.41 \\
\hline $\mathrm{NPK}+\mathrm{Zn}+\mathrm{Fe}+\mathrm{Mn}$ & 40.8 & 49.5 & 42.5 & 44.3 & 44.27 & 41.5 & 50.2 & 43.2 & 44.9 & 44.94 \\
\hline NPK +10 t FYM ha-1 & 38.3 & 46.6 & 39.8 & 42.6 & 41.82 & 39.0 & 47.2 & 40.4 & 43.3 & 42.49 \\
\hline $\begin{array}{l}\text { NPK+ Zn +Fe +Mn + } \\
\text { Vermicompost @ } 3 \text { t ha }{ }^{-1}\end{array}$ & 44.9 & 55.1 & 46.1 & 49.3 & 48.88 & 45.6 & 55.8 & 46.8 & 50.0 & 49.54 \\
\hline Control & 23.0 & 27.4 & 24.1 & 25.7 & 25.07 & 23.7 & 28.1 & 24.8 & 26.4 & 25.73 \\
\hline Mean & 33.35 & 40.90 & 36.67 & 38.43 & & 34.02 & 41.57 & 37.34 & 39.09 & \\
\hline & $\mathbf{W}$ & $\mathbf{N}$ & & & & $\mathbf{W}$ & $\mathbf{N}$ & & & \\
\hline SEm & 0.40 & 0.29 & & & & 0.45 & 0.36 & & & \\
\hline CD@ 5\% & 1.38 & 0.81 & & & & 1.57 & 1.01 & & & \\
\hline CV & 5.83 & 6.64 & & & & 6.55 & 8.14 & & & \\
\hline
\end{tabular}


Effect of nutrients applications on head recovery $(\%)$ in rice grain

The ranges of variation in head recovery percent in grain were 60.32 and $61.88 \%$ and 60.99 to $62.55 \%$ in first and second years, respectively. All the treatments had statistically higher head recovery percent values than control. All the treatments were statistically superior to control in respect of head recovery percent. Among the nutrients application levels head recovery percent increase statistically with $\mathrm{NPK}+\mathrm{Zn}+\mathrm{Fe}+\mathrm{Mn}$ +Vermicompost @ 3 ton $\mathrm{ha}^{-1}$ as compare to control during both the year. Addition of $\mathrm{Zn}$ $\mathrm{Fe}, \mathrm{Mn}$ with NPK increased head recovery in grain as in comparison of all nutrient applications during both the year (Table 4). Similar finding was also reported by Srivastav et al., (2009) and Kumar et al., (2017).

\section{Effect of nutrients application on grain yield $\left(\mathbf{q} \mathbf{h a}^{-1}\right)$}

It is clear from the Table (5) showed that the grain yield $\left(\mathrm{qha}^{-1}\right)$ was influenced significantly due to different nutrient applications during both of the year. The grain yield ranged was varied from 18.16 to $36.58 \mathrm{q} \mathrm{ha}^{-1}$ during first year and 18.83 to $37.24 \mathrm{qha}^{-1}$ during second year, respectively. Among the nutrient application, NPK $+\mathrm{Zn}$ $+\mathrm{Fe}+\mathrm{Mn}+$ Vermicompost @ 3 ton $\mathrm{ha}^{-1}$ application was recorded significantly highest grain yield with the ranged 33.00 to $41.97 \mathrm{ha}^{-1}$ and 33.67 to $42.63 \mathrm{qha}^{-1}$ as compared to control treatment during both of the year. The lowest grain yield was noticed in control plot viz., 16.20 and $20.40 \mathrm{qha}^{-1}$ to 16.87 to 21.07 qha $^{-1}$ during 2015-16 and 2016-17, respectively.

\section{Effect of nutrients application on straw yield}

It is perusal the data given in Table (6) showed that straw yield influenced significantly due to different nutrients application of rice crop during both of the year. The straw yield ranged was varied from 25.07 to $48.88 \mathrm{qha}^{-1}$ during first year and 25.73 to $49.54 \mathrm{qha}^{-1}$ during second year of study period. The straw yield was recorded significantly highest under $\mathrm{NPK}+\mathrm{Zn}+\mathrm{Fe}$ $+\mathrm{Mn}+$ Vermicompost @ 3 ton $\mathrm{ha}^{-1}$ with the ranged varied from 44.49 to $55.10 \mathrm{qha}^{-1}$ during first year and 45.60 and $55.80 \mathrm{q} \mathrm{ha}^{-1}$ during second year of the observation followed by $\mathrm{NPK}+\mathrm{Zn}+\mathrm{Fe}+\mathrm{Mn}$ and NPK +10 t FYM ha ${ }^{-1}$, respectively. The lowest straw yield was noticed under the control plot with ranged varied from 23.0 to $27.4 \mathrm{q} \mathrm{ha}^{-1}$ and 23.7 to 28.1 qha $^{-1}$ during 2015-16 and 2016-17. These findings of present investigation are supported by those of Srivastava (2009), Mahmud et al., (2016).

In conclusion, it is palpable from the data Tables that biological yield, hulling, milling, head rice recovery, grain yield, and straw yield varied from with mean value of 43.22$86.78 \mathrm{q} \mathrm{ha}^{-1}, 75.91-78.14 \%$, 64.49-66.80\%, 18.16-37.24 q ha-1, 25.07-49.54 q ha ${ }^{-1}$, respectively. Use of nitrogen, phosphorus, potassium along with micronutrients and pesticides and organic manures recorded more improvement in production and productivity of basmati rice during both kharif season. Minimum biological yield, hulling $\%$ and other yield attributes were observed lowest in control plots. Imbalance use of major and micro nutrient and pesticides causes poor nutrition status/ availability of nutrients resulting adverse impact on productivity of rice grain in such type of irrigated rice soil. These findings are comparable to those reported by Kumar et al., (2017) and Tripathi et al., (2018).

\section{References}

APEDA, (2019). India Export of Agro Food
Products: 
Report/Country Wisee Basmati Rice.

Bandyopadhyay, S. and Roy N. C. (1992).

Rice process technology Oxford and IBH Publishing Co., Pvt., Ltd., New Delhi pp: $15 \& 28$.

Bhosale, $\mathrm{S}$ and Vijayalakshmi, D. (2015).Processing and Nutritional Composition of Rice Bran. Current Research in Nutrition and Food Science,3(1): 74-80.

Black, C.A. (1965). Methods of soil analysis. American Society of Agronomy, Monography 9, Madison, Wisconsin, pp. 1572.

Bligh., and Heather., (2000). Detection of adulteration of Basmati rice with non- premium long- grain rice. International Journal of Food Science \& Technology. 35. 257 - 265. 10.1046/j.1365-2621.2000.00390.x.

Bouyoucos G.J. (1962). Hydrometer method improved for making particle analysis of soils. Agronomy J., 54: 464.

Chandel, S.R.S. (1998). Advance agriculture statics, $2^{\text {nd }}$ Edition, Kalyani Publication

Das R., Vanita J., Smitha A., Barman M., and Srivastava G.C., (2006). Kinetics of nitrate uptake system in wheat genotypes. Indian J. Plant Physiol., Vol. 11, No. 2, (N.S.) pp. 160-165

Dixit, K.G. and Gupta, B.R. (2000). Effect of farm yard manure, chemical and biofertilizers on yield and quality of rice (Oryza sativa L.) and soil properties. J. of the Indian Society of Soil Science, 48 (4): 773- 780.

Esfahani, A., Pirdashti H. and Niknejhad Y. (2014). Effect of Iron, Zinc and Silicon Application on Quantitative Parameters of Rice (Oryza sativa L. CV.Tarom Mahalli). Int. J. of Farming and Allied Sciences, 3 (5): 529-533.

FAO (2011). Training Manual on Evaluation of Pesticide residue for Estimation of Maximum Residue Levels and Calculation of Dietary Intake. Identity and Physical and Chemical Properties, pg. n. 9-26.

Islam K.M.Z., Sumelius, J., and Bäckman S. (2012). Do differences in technical efficiency explain the adoption rate of HYV rice? Evidence from Bangladesh Agric. Econ. Rev. Thessaloniki, 13 (2012), pp.93-110

Jackson, M.L. (1967). Soil chemical analysis. Prentice Hall of India Pvt. Ltd., New Delhi, pp. 498.

Liu, T.N., Wang, Z.L., and Cai. T. (2016). Canopy apparent photosynthetic characteristics and yield of two spiketype wheat cultivars in response to row spacing under high plant density. P LoS One $11 . \quad$ doi: 10.1371/journal.pone.0148582

Kumar, R. and Kureel, R.S. (2017). Effect of nitrogen and phosphorus on yield and quality of scented rice $c v$. Pusa Basmati-1. J. of Pharmacognosy and Phytochemistry, 6(4): 1418-1420.

Mahmud, A. M., Shamsuddoha, A.T.M., Issak, M. Haque M. N. and Achakzai, A. K.K. (2016). Effect of Vermicompost and Chemical Fertilizer on the Nutrient Content in Rice Grain, Straw and Post Harvest Soil. MiddleEastJ. Sci. Res., 24(2): 437-444.

Olsen, S.R., Cole, C.L., Watanabe, F.S., and Dean, D.A., (1954). Estimation of available phosphorus in soils by extraction with sodium bicarbonate. USDA, Circ, pp. 939

Singh, S., Chhokar R.S., Gopal, R. and Kumar, V. (2009b). Integrated weed management- a key for success of direct seeded rice in the Indo - Gangetic Plains. Int. Rice Research Institute (IRRI), Los Banos, Philippines, pp. 261278

Singh, R. and Sinha, A.P. (2004). Comparative efficacy of local bioagents, commercial bio-formulation and fungicide for the management of 
sheath blight of rice under glass house conditions. Indian Phytopathology, 57: 494-496.

Srivastava, P., Srivastava, P.C. and Singh U.S. (2009). Effect of integrated and balanced nutrient application on soil fertility, yield and quality of Basmati rice. Archives of Agronomy and Soil Science, 55(3): 265-284.

Stanford, S and L. English. (1949). A use of Flame Photometer in rapid soil tests of $\mathrm{K}$ and Ca. Agron. J., 41: 446-447.

Subbiah, B.V. and Asija, G.L. (1956). Procedure for estimation of available nitrogen in soil. Curr. Sci., 25:259-260

Tejada, M., Hernandez, M.T. and Garcia, C. (2009). Soil restoration using composted residues: Effects on soil properties. Soil Tillage Research, 102: 109-117.

Tripathi, B.N., Singh, R.K., Tripathi, C.K.,
Nand K. and Dhankar A. (2018). Effect of nutrients management practices on yield, nutrients uptake and quality characteristics of rice (Oryza sativa L.) in central alluvial tract of Uttar Pradesh. Annals of Plant and Soil Research. pp 39- 44.

Tripathi, D.K., Singh, S., Singh, S., Mishra, S., Chauhan, D.K. and Dubey, N.K. 2015. Micronutrients and their diverse role in agricultural crops: Advances and future prospective. Acta Physiol Plant, 37: 139.

Zhao, Yanan; He, Xinhua; Xingcheng, Huang; Zhang, Yueqiang; Shi, and Xiao-Jun. (2016). Increasing Soil organic matter enhances inherent soil productivity while offsetting fertilization effect under a rice cropping system. Sustainability. 8. 10.3390/su8090879.

\section{How to cite this article:}

Anurag Dhankar, B.N. Tripathi, Ravi Dhanker, R.K. Pathak, Anil Kumar, Puspendra Kumar and Vivek Kumar. 2020. Integrated Effect of Nutrient and Pesticide Management on Production and Productivity of Rice Variety Pusa Basmati-1509. Int.J.Curr.Microbiol.App.Sci. 9(08): 1559-1573. doi: https://doi.org/10.20546/ijcmas.2020.908.180 